\title{
THE RELATION BETWEEN ESCHERICHIA COLI SURFACE FUNCTIONAL GROUPS' COMPOSITION AND THEIR PHYSICOCHEMICAL PROPERTIES
}

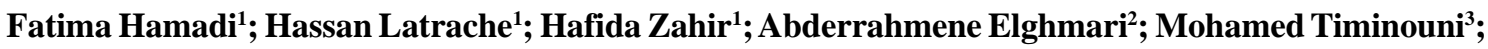 \\ Mostapha Ellouali ${ }^{1}$
}

${ }^{1}$ Equipe de recherche: Microbiologie et biochimie appliquée á L'agroalimentaire, L'environmental et la Santé, FST, Beni Mellal, Marocco; ${ }^{2}$ Laboratoire de Télédétection et SIG, FST, Beni Mellal, FST, Beni Mellal; ${ }^{3}$ Laboratoire de la microbiologie et de la biologie moléculaire, Institut Pasteur, Casablanca, Marocco.

Submitted: March 07, 2007; Returned to authors for corrections: July 02, 2007; Approved: January 18, 2008.

\begin{abstract}
Escherichia coli surface characteristics including hydrophobicity, electrophoretic mobility and surface functional groups' composition were investigated. These characteristics were determined respectively by water contact angle measurements, microelectrophoresis and x-ray photoelectron spectroscopy (XPS). The relation between the physicochemical properties and functional groups' composition was also examined. The electrophoretic mobility at $\mathrm{pH} 7$ appeared to be governed on the cell surface by the $(\mathrm{O}=\mathrm{C})$ functional groups. The cell surface's hydrophilicity was associated with high levels of $(\mathrm{C}-(\mathrm{O} . \mathrm{N}))$ and $(\mathrm{OH}-$ $(\mathrm{C}-\mathrm{O}-\mathrm{C}))$ functional groups, whereas the cell surface's hydrophobicity was associated with $(\mathrm{C}-(\mathrm{C}, \mathrm{H}))$ functional groups.
\end{abstract}

Key words: Escherichia coli, surface functional groups, hydrophobicity, electrophoretic mobility.

\section{INTRODUCTION}

Escherichia coli (E. coli) is the most frequent nosocomial pathogen and a major contaminant in catheter associated with urinary tract infections (UTI) (21). The adhesion of E. coli is thought to be the first step in the pathogenesis of this type of infection. A previous study has demonstrated that hydrophobicity plays an important role in a wide range of microbial infections (10). Therefore, the understanding of the adhesion process requires detailed knowledge of the physicochemical properties and their chemical origins.

The microbial adhesion to a surface is mediated by different physicochemical interactions including lifsthitz van der Waals, electrostatic and acid-bases interactions. These interactions depend on the substratum and the bacterial surface's physicochemical properties, such as hydrophobicity (25), charge $(9,14)$ and electron donor /electron acceptor $(26)$. All these properties are determined by the outermost cell surface's chemical composition. In order to understand the adhesion process, most previous works $(2,3,8,19)$ have used this chemical composition to explain the origin of the physicochemical properties.

The chemical composition of cell surface was determined by X-ray photoelectron spectroscopy (XPS). This technique provides information on the elemental and chemical functions' composition of the outermost cell surface ( 2 to $5 \mathrm{~nm}$ ) $(3,7)$. Moreover, the XPS data can be converted into a molecular composition in terms of proteins, polysaccharides and hydrocarbon-like compounds using a model constituent (11). Understanding the origin of physicochemical properties requires an investigation of the relation between all phyiscochemical properties and all XPS data including elemental, molecular and functional composition. For instance, most previous works $(2,3,5,6,8,13,15,17,19,20,22-24)$ have explained the origin of hydrophobicity and electrophoretic properties by the relation between these properties and the elemental composition on one hand and the molecular composition on the other hand.

*Corresponding Author. Mailing address: Faculté des sciences et techniques, Dep. Biologie, Equipe de recherche: Microbiologie et biochimie, appliquée à l'agroalimentaire, l'environnement et la santé, Beni Mellal, B.P. 523. E-mail: latracheh@yahoo.fr 
Functional groups' composition was obtained by the decomposing XPS peaks, where each peak is specific for a given element. Previous studies $(11,12,15)$ have examined the relation between the functional groups and the elemental composition in order to determine the nature of the molecular constituents present at the cell surface. Information about the role of functional groups in determining the origin of physicochemical properties is very limited $(6,20)$.

In this study, we have used the functional groups' composition to explain the origin of E. coli surface's physicochemical properties. The relation between the functional groups composition and hydrophobicity on one hand and the surface charge on the other hand was examined.

\section{MATERIALS AND METHODS:}

\section{Bacteria}

Three $E$. coli strains used are: (i) HB101, a K12 strain, nonpathogenic; (ii) 382 and (iii) AL52, both isolated from patients with urinary tract infection. Each strain was grown either in Liquid Luria Bertani medium (LLB) or on Solid Luria Bertani agar (SLB). Bacteria were cultured at $37^{\circ} \mathrm{C}$ in two steps: preculture during $18 \mathrm{~h}$ and culture during $22 \mathrm{~h}$.

\section{Surface physicochemical characterisation}

Bacteria electrical properties were characterized by measuring their electrophoretic mobility. The cells were washed twice with $0.9 \% \mathrm{NaCl}$ solution, and treated with $1 \%$ formol solution during $20 \mathrm{~min}$ at room temperature to eliminate the bacterial motility. The formol was removed by centrifugation and the bacteria were suspended in distilled water. A portion of this suspension was diluted in $10^{-3} \mathrm{M} \mathrm{KNO}_{3}$. The $\mathrm{pH}$ was adjusted by $\mathrm{HNO}_{3}$ or $\mathrm{KOH}$ and the electrophoretic mobility was determined with a zetameter Zm77 (Zeta-meter Incorporation, New York).

Cell surface hydrophobicity was estimated by water contact angle $(\theta \mathrm{w})$ measurement on cell lawn using the sessile drop method (4). Briefly, bacteria were deposited on membrane filters (0.45 um Sartorius), after a standard drying time (90 $\mathrm{min}$ ) contact angle were measured with a goniometer (Kruss -Germany).

\section{XPS analysis}

Bacteria were collected by centrifugation, suspended in distilled water and washed twice. The pellet was kept frozen at $-80^{\circ} \mathrm{C}$. Samples were lyophilized in a Lyovac GT4 (Leyobold Heraeus). The elemental composition of the cell surface was determined by XPS using a SSX 100 Spectrometer (Model 206, Surface Science Instruments), with A1-anode for X-ray production; experimental details were described previously (18).

The functional composition was obtained by the decomposition of XPS peaks, using least-squares curves fitting.
The carbon peak was decomposed into three components set at $284.8 \mathrm{eV}, 286.2 \mathrm{eV}, 287.9 \mathrm{eV}$ representing carbon singly bound to carbon and hydrogen $(\mathrm{C}-(\mathrm{C}, \mathrm{H}))$, carbon singly bound to oxygen or nitrogen $(\mathrm{C}-(\mathrm{O}, \mathrm{N}))$ and carbon making a double bond or two single bonds with oxygen $(\mathrm{C}=\mathrm{O})$ respectively. The oxygen peak was decomposed into two components set at $531.2 \mathrm{eV}$, $532.6 \mathrm{eV}$ representing oxygen making a double bond with carbon $(\mathrm{O}=\mathrm{C})$ and oxygen involved in hydroxide or ether functions (OH, C-O-C).

\section{RESULTS AND DISCUSSION}

\section{Surface physicochemical analysis}

E. coli cell surface's hydrophobicity and electrophoretic mobility (EPM) are presented in Table 1. Values of water contact angle obtained from all $E$. coli strains ranges from $17^{\circ}$ (AL52 strains (SLB)) to $36^{\circ}$ (382 strains (LLB)), indicating that these strains are hydrophilic. From Table 1, it is also shown that the EPM at $\mathrm{pH} 7$ is ranging from -4.39 (HB 101 strains (LLB)) to -1.98 (AL52 strains (LLB)).

Functional groups' composition of E. coli cell surface, determined by XPS, is given in Table 2 . We found that a relatively high proportion of carbon peak was in the $(\mathrm{C}-(\mathrm{C}, \mathrm{H}))$ form. These observations were not consistent with Mozes et al. (1988) results that showed that in gram negative bacteria, a relatively high proportion of carbon was in the $\mathrm{C}-\mathrm{O}$ or $\mathrm{C}-\mathrm{N}$ form. Most of the oxygen was engaged in a hydroxide form. These observations were, however, consistent with Mozes et al. (1988) finding.

\section{Surface charge and functional groups' composition}

In order to point out the groups involved in determining the surface charge, the majority of the works $(1,2,18,19,20,22)$ have examined the relation between the elemental composition determined by XPS and the electrophoretic mobility at $\mathrm{pH} 4$ or at $\mathrm{pH}$ 7. In these studies, it was reported that the phosphate groups play a predominant role in the surface charges

Table 1. E. coli physicochemical properties

\begin{tabular}{cccc}
\hline $\begin{array}{c}\text { E. coli } \\
\text { Strains }\end{array}$ & $\begin{array}{c}\text { Culture } \\
\text { medium }\end{array}$ & $\begin{array}{c}\mathrm{EPM}(7) \text { at } \mathrm{pH} \\
\left(10^{-8} \mathrm{~m}^{2} \mathrm{~V}^{-1} \mathrm{~s}^{-1}\right)\end{array}$ & $\begin{array}{c}\text { water contact } \\
\text { angle }\left(\theta^{\circ}\right)\end{array}$ \\
\hline AL52 & LLB & $-1.98(0.20)$ & $20(2)$ \\
& SLB & $-2.5(0.09)$ & $17(2)$ \\
HB101 & LLB & $-4.39(0.05)$ & $28(3)$ \\
& SLB & $-3.44(0.06)$ & $26(3)$ \\
$\mathbf{3 8 2}$ & LLB & $-2.92(0.36)$ & $36(3)$ \\
& SLB & $-3.46(0.02)$ & $25(2)$ \\
\hline
\end{tabular}

EPM: Electrophoretic mobility at $\mathrm{pH} 7$; results are mean values of two replicate experiments with simple deviation in parentheses.. 
Table 2. Surface functional composition of three $E$. coli cultivated under different conditions (atom fraction (\%) excluding hydrogen; mean of at least two analyses of cells from independent cultures).

\begin{tabular}{ccccccc}
\hline E. coli & Culture & $\mathrm{C}-(\mathrm{C}, \mathrm{H})$ & $\mathrm{C}-(\mathrm{O}, \mathrm{N})$ & $\mathrm{C}=\mathrm{O}$ & $\mathrm{O}=\mathrm{C}$ & $\mathrm{OH}, \mathrm{C}-\mathrm{O}-\mathrm{C}$ \\
Strains & medium & $284.8 \mathrm{eV}$ & $286.2 \mathrm{eV}$ & $287.9 \mathrm{eV}$ & $531.2 \mathrm{eV}$ & $532.6 \mathrm{eV}$ \\
\hline \multirow{2}{*}{ AL52 } & LLB & 32.1 & 24.2 & 9 & 6.8 & 20.8 \\
& SLB & 24.6 & 26.9 & 11 & 8.2 & 22.8 \\
HB101 & LLB & 36.5 & 20.1 & 8.6 & 10.6 & 16.2 \\
& SLB & 38.7 & 19.5 & 8.2 & 9.5 & 15.9 \\
$\mathbf{3 8 2}$ & LLB & 38.5 & 18.5 & 9.9 & 10.2 & 12.2 \\
& SLB & 30.2 & 21.8 & 10.7 & 10.5 & 16.2 \\
\hline
\end{tabular}

It is known that carboxylic acid is included in $(\mathrm{O}=\mathrm{C})$ and in $(\mathrm{C}=\mathrm{O})$ functional groups, however we suggest that the role of $(\mathrm{O}=\mathrm{C})$ in the surface charge could be attributed to the presence of a carboxylic acid in this function. These findings reveal that carboxyl groups contribute to the surface charge determination, and are in accordance with other reports based on modelled surface charge $(3,8,16)$.

Our data do not suggest any correlation between the electrophoretic mobility and other functional groups. The absence of a relation between the $\mathrm{C}=\mathrm{O}$ and surface charge could be attributed to a proportion of oxygen bound to carbon in $\mathrm{C}=\mathrm{O}$ form and to oxygen bound to carbon in $\mathrm{O}=\mathrm{C}$ form. development while the participation of carboxyl groups in this charge was minor.

Few studies $(3,8,16)$ have reported that both of the carboxyl and phosphate groups contribute in the determination of the cell surface charge. These studies have modelled the surface charge according to the surface chemical composition as given by XPS. Investigating the relation between electrophoretic mobility and the modelled surface charge has emphasized the role of carboxylic groups in the surface charge.

All previous studies were based only on elemental composition to explain the origin of the surface charge. In this study we attempt to investigate the role of functional groups' composition of $E$. coli surface charge. Fig. 1 shows that there is a good correlation between the electrophoretic mobility at $\mathrm{pH} 7$ and the $(\mathrm{O}=\mathrm{C})$ functional groups. This implies that the electrophoretic mobility becomes more negative as the $(\mathrm{O}=\mathrm{C})$ functional group increases. These results suggest that $(\mathrm{O}=\mathrm{C})$ functional groups play an important role in determining E. coli negative surface charges.

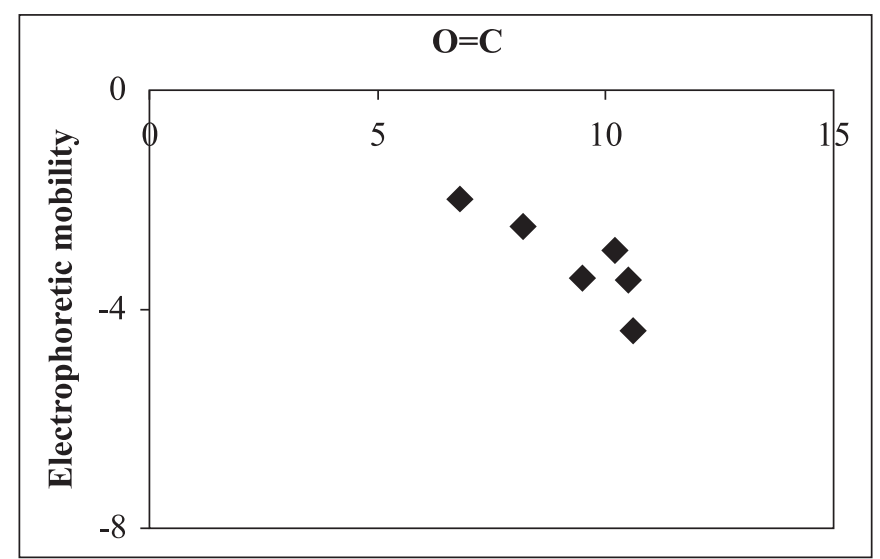

Figure 1. Relation between electrophoretic mobility and $\mathrm{O}=\mathrm{C}$ function $(r=0.78)$

\section{Hydrophobicity and functional group's composition}

Several techniques were suggested for the measurement of cell surface hydrophobicity including contact angle, hydrophobic interaction chromatography and microbial adhesion to hydrocarbon. Most previous studies $(3,6,13,17$ 20,22) investigated the role of elemental and molecular composition in cell surface hydrophobicity estimated by different methods. However, attempts to relate the cell surface hydrophobicity to functional groups composition are scarce $(6,20)$. In this study, we attempt to understand the origin of cell surface hydrophobicity measured by water contact angle on the basis of the functional groups. Fig. 2 presents the correlation between the functional groups composition and water contact angle. We observed that the cell surface hydrophobicity was inversely correlated to the $(\mathrm{C}-(\mathrm{O}, \mathrm{N}))$ function (Fig. 2a) and the (OH, C-O-C) function (Fig. 2b). It was also directly correlated to the (C-(C,H)) function (Fig. 2c). The results obtained with $(\mathrm{C}-(\mathrm{O}, \mathrm{N}))$ function were consistent with the results taken from study on Lactobacillus (6). Mozes et al. (1988) have used the hydrophobic interaction chromatography to measure the cell surface hydrophobicity. In agreement with our findings, they showed that this property correlates with $(\mathrm{C}-(\mathrm{C}, \mathrm{H}))$ function.

It is generally accepted that the presence of oxygen or nitrogen favour interactions with water molecules (via $\mathrm{H}$-bonds) and should reduce hydropobicity. This could explain the decrease of water contact angle with an increase of $(\mathrm{OH}, \mathrm{C}-\mathrm{O}-$ C) and $(\mathrm{C}(\mathrm{O}, \mathrm{N}))$ functional groups which contain the oxygen and nitrogen.

According to Dufêrene et al. 1999, the (OH, C-O-C), (O=C) and $(\mathrm{C}-(\mathrm{C}, \mathrm{H}))$ functions reflected polysaccharides, proteins and hydrocarbons respectively. Cuperus et al. 1992 reported that $(\mathrm{C},(\mathrm{O}, \mathrm{N}))$ and $(\mathrm{C}=\mathrm{O})$ indicated the presence of polysaccharides and proteins respectively. In order to confirm this hypothesis, we examined the relation between the functional groups and the molecular composition determined previously by using the model constituent (16). In Fig. 3, a 


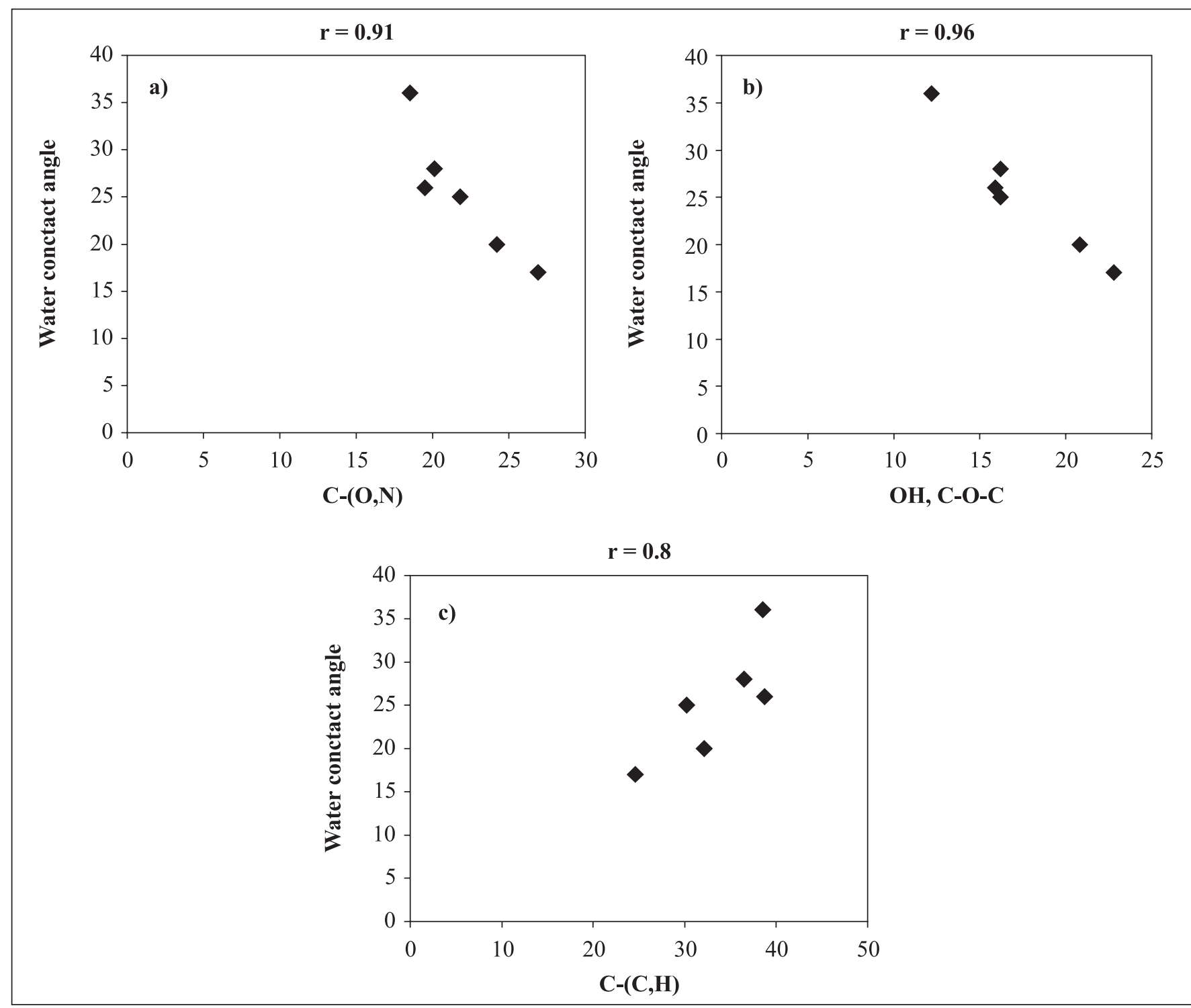

Figure 2. Variation of $E$. coli cell surface hydrophobicity as a function of functional group composition: (a) $(\mathrm{C}-(\mathrm{O}, \mathrm{N}))$; (b) $(\mathrm{OH}, \mathrm{C}-$ $\mathrm{O}-\mathrm{C}) ;(\mathrm{c})(\mathrm{C}-(\mathrm{C}, \mathrm{H}))$

good correlation was found between polysaccharides, proteins, hydrocarbons and $(\mathrm{OH}, \mathrm{C}-\mathrm{O}-\mathrm{C}$ or $(\mathrm{C},(\mathrm{O}, \mathrm{N})) ;(\mathrm{C}=\mathrm{O})$; $(\mathrm{C}-(\mathrm{C}, \mathrm{H})$ respectively. Our results are consistent with literature data regarding functions reflecting polysaccharides, hydrocarbons and proteins. According to Mozes et al. (1988) findings, the increase of cell surface hydrophobicity with C$(\mathrm{C}, \mathrm{H})$ was due to the presence of hydrocarbon. The decrease of cell surface hydrophobicity with the increase of $(\mathrm{OH}, \mathrm{C}-\mathrm{O}-$ $\mathrm{C})$ and $(\mathrm{C},(\mathrm{O}, \mathrm{N})$ could be explained by the presence of polysaccharides. These results show that $(\mathrm{OH}, \mathrm{C}-\mathrm{O}-\mathrm{C})$ and $(\mathrm{C},(\mathrm{O}, \mathrm{N})$ functions play an important role in the determination of $E$. coli cell surface hydrophilicity. Such findings were in agreement with the previous work reported by other researchers $(3,22)$ where it was shown that hydrophilicity assessed by water contact angle was related to the presence of polysaccharides.

Our results do not show any relation between $(\mathrm{C}=\mathrm{O})$ function and water contact angle. Since this function indicates the presence of proteins, it suggests that proteins do not contribute to the determination of $E$. coli cell surface hydrophobicity. Several groups $(5,6,22)$ have reported that higher water contact angle is consistent with a larger amount of surface proteins. These reports implies the role of proteins in determining the cell surface hydrophobicity by considering that the nitrogen /carbon 


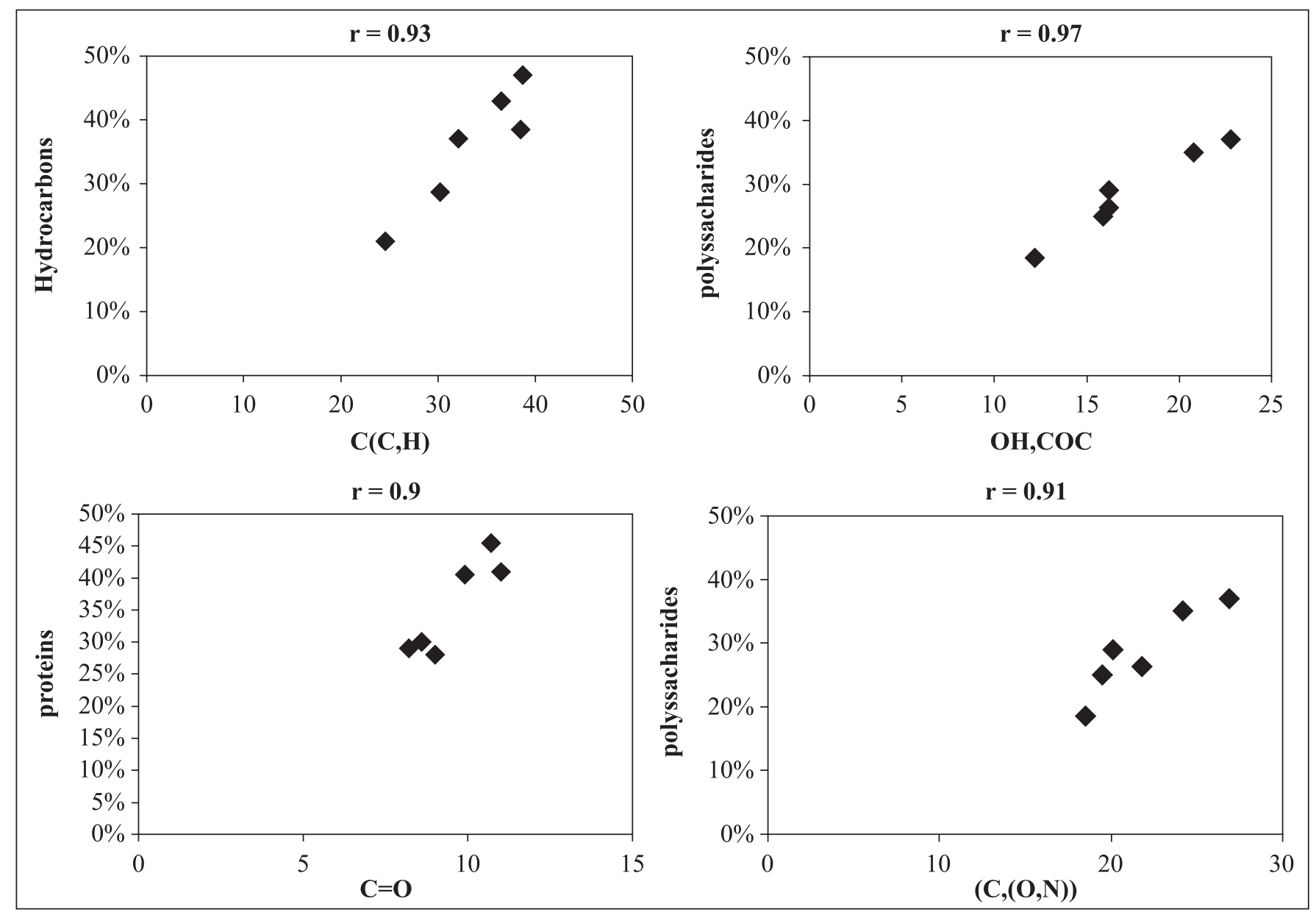

Figure 3. Relation between molecular composition and functional groups composition.

(N/C) ratio reflects the proteins and by studying the relation between the N/C ratio and the water contact angle. Our previous work on $E$. coli has also shown that the N/C ratio correlates with water contact angle (17) but we did not show the role of proteins determined by model constituent in cell surface hydrophobicity. We conclude, therefore, that the parameters reflecting the proteins should be considered with caution. Finally, it can be noted that a better understanding of the origin of the physicochemical properties requires the investigation of the role of all parameters of the surface chemical composition determined by XPS.

\section{ACKNOWLEDGEMENT}

We thank Dr Mohammed Bourdi, (National Institutes of Health, Bethesda, MD) for providing helpful comments on the manuscript.

The Scientific Research of the french community in belgium (concerted Action Physical chemistry of interfaces and biotechnology) is gratefully acknowledged. The authors wish to thank Dr.A.J. Léonard for his help in data treatment.

\section{RESUMO}

\section{Relação entre a composição dos grupos funcionais da superfície de Escherichia coli e suas propriedades fisicoquímicas}

Características de superfície de Escherichia coli, tais como hidrofobicidade, mobilidade eletroforética e composição dos grupos funcionais de superfície, foram estudadas. Essas características foram determinadas por medidas de angulo de contato com água, microeletroforese e espectroscopia fotoeletrônica de raio-X (XPS), respectivamente. A relação entre as propriedades fisicoquímicas e a composição dos grupos funcionais foi também examinada. Aparentemente, a mobilidade eletroforética em pH 7 é controlada na superfície celular pelos grupos funcionais $(\mathrm{O}=\mathrm{C})$. A hidrofilicidade da superfície celular 
estava associada com altos níveis dos grupos funcionais [C$(\mathrm{O} . \mathrm{N})]$ e [OH-(C-O-C)], enquanto a hidrofobicidade estava associada com os grupos funcionais $[\mathrm{C}-(\mathrm{C}, \mathrm{H})]$.

Palavras-chave: Escherichia coli, grupos funcionais de superfície, hidrofobicidade, mobilidade eletroforética

\section{REFERENCES}

1. Amory, D.E.; Mozes, N.; Hermesse, M.P.; Leonard, A.J.; Rouxhet, P.G. (1988). Chemical analysis of the surface of microorganisms by X-ray photoelectron spectroscopy FEMS Microbiol. Let., 49, 107110.

2. Amory, E.; Rouxhet, P.G. (1987). Surface properties of Saccharomyces and Saccharomyces carlsbergensis: chemical composition, electrostatic charge and hydrophobicity. Biochimica Biophysica Acta, 938, 61-70.

3. Boonaert, C.J.; Rouxhet, P.G. (2000). Surface of lactic acid bacteria: Relationship between chemical composition and physicochemical properties. Appl. Environ. Microbiol., 66(6), 2548-2554.

4. Busscher, H.J.; Weerkamp, A.H.; Van der Mei, H.C.; Van Pelt, A.W. J.; de Jong, H.P.; Arends, J. (1984). Measurement of the surface free energy of bacterial cell surface and its relevance for adhesion. Appl. Environ. Microbiol., 48(5), 980-983.

5. Cowan, M.N.; Van der Mei, H.C.; Rouxhet, P.G.; Busscher, H.J. (1992). physico-chemical and structural properties of the surfaces of Peptostreptococcus micros and Streptococcus mitis as compared to those of mutans streptococci, streptococcus sanguis and streptococcus salivarius. J. Gen. Microbiol., 138, 2707-2714.

6. Cuperus, P.L.; Van der Mei, H.C.; Reid, G.; Bruce, A.W.; Khoury, A. H.; Rouxhet, P.G.; Busscher, H.J. (1993). Physicochemical surfaces characteristics of urogenital and poultry lactobacilli. J. Colloid Interf. Sci., 156(2), 319-324.

7. Dengis, P.B.; Gerin, P.A.; Rouxhet, P.G. (1995). X-rayphotoelectron spectroscopy analysis of biosurfaces: examination of performances with yeast cells and related model compounds. Colloids Surf. B: Biointerfaces, 4(4), 199-211.

8. Dengis, P.B.; Rouxhet, P.G. (1997). Surface properties of top- and bottom fermenting yeast. Yeast, 13(10), 931-943.

9. Dickson, J.S.; Koohmaraie, M. (1989). Cell surface charge characteristics and their relationship to bacterial attachment to meat surfaces. Appl. Environ. Microbiol., 55(4), 832-836.

10. Doyle, R. (2000). Contribution of the hydrophobic effect to microbial infection. Microb Infect., 2(4), 391-400.

11. Dufrêne, Y.F.; Boonaert, C.J.P.; Rouxhet, P.G. (1999). Surface analysis by X-ray photoelectron spectroscopy in study of bioadhesion and biofilms. Method Enzymol., 310, 375-389.
12. Dufrêne, Y.F.; Rouxhet, P.G. (1996). Surface composition, surface properties, and adhesiveness of azospirillum brasilense-variation during growth. Can. J. Microbiol., 42: 548-556

13. Dufrêne, Y.F.; Rouxhet, P.G. (1996).X-ray photoelectron spectroscopy analysis of the surface composition of Azospirillum brasilense in relation to growth conditions. Colloids Surf. B. Biointerfaces, 7(5-6), 271-279

14. Gannon, J.T.; Manilal, V.B.; Alexander, M (1991). Relationships between cell surface properties and transport of bacteria through soil. Appl. Environ. Microbiol., 57(1), 190-193

15. Gerin, P.A.; Dufrêne, Y.; Bellon-Fontaine, M.N.; Asther, M. Rouxhet, P.G. (1993). Surface properties of the conidiospores of phanerochaete chrysosporium and their relevance to pellet formation. J. Bacteriol., 175(16), 5135-5144.

16. Hamadi, F.; Latrache, H.; Elghmari, A.; Zahir, H.; Mabrrouki, M.; El Bouadili, A. (2005). Determination of Escherichia coli negative charge concentration and its variation with $\mathrm{pH}$ J. Surf. Anal , 12(3), 293-302

17. Latrache, H.; Elghmari, A.; Karroua, M.; Hakkou, A.; Ait Mousse, H.; Bourlioux, P. (2002). Relations between hydrophobicity tested by three methods and surface chemical composition of Escherichia coli. New Microbiol., 25 (1), 75-82.

18. Latrache, H.; Mozes, N.; Pelletier, C.; Bourlioux, P. (1994). Chemical and physicochemical properties of Eschercia coli: variations among three strains and influence of culture conditions. Colloids Surf. B: Biointerfaces, 2(1-3), 47-56.

19. Mozes, N.; Amory, D.E.; Leonard, A.J.; Rouxhet, P.G. (1989) Surface properties of microbial cells and their role in adhesion and flocculation. Colloids Surf., 42, 313-329.

20. Mozes, N.; Léonard, A.J.; Rouxhet, P.G. (1988). On the relation between the elemntal surface composition of yeast and bacteria and their charge and hydrophobicity. Biochim. Biophys. Acta, 945, 324-334.

21. Platt, R., Plok, B.F.; Murdock, B.; Rosner, B. (1982). Mortality associated with nosocomial urinary tract infection. N. Engl. J. Med., 307, 637-642

22. Van der Mei, H.C.; Busscher, H.J. (1997). The use of X-ray photoelectron spectroscopy for the study of oral streptococcal cell surfaces. Adv. Dent. Res., 11(4), 388-394.

23. Van der Mei, H.C.; Genet, M.J.; Weerkamp, A.H.; Rouxhet, P.G.; Busscher, H.J. (1989). A comparison between the elemental surface of oral streptococci with and without adsorbed salivary constituents. Archs Oral Biol., 34(11), 889-894.

24. Van der Mei, H.C.; Handley, P.S.; Busscher, H.J. (1992). Depth profiling of the elemental surface composition of the oral microorganism S. Salivarius HB and fibrillar mutants by X-ray photoelectron spectroscopy. Cell Biophysics., 20, 99-110.

25. Van Loosdrecht, M.C.M.; Lyklema, J.; Norde, W.; Schraa, G.; Zehnder, A.J.B. (1987). The role of bacterial cell wall hydrophobicity in adhesion. Appl. Environ. Microbiol., 53(8), 1893-1897.

26. Van Oss, C.J. (1993). Acid-base interfacial interactions in aqueous media. Colloids Surf. A. Physicochem. Eng. Aspects, 78, 1-49. 